\title{
Predictive equations for soil shear-wave velocities of Hungarian soils based on MASW and CPT measurements around Györ
}

\author{
O. Kegyes-Brassai ${ }^{1} \cdot$ R. P. Ray ${ }^{1} \cdot$ P. Tildy $^{2}$
}

Received: 20 June 2015/Accepted: 17 October 2015/Published online: 12 November 2015

(C) Akadémiai Kiadó 2015

\begin{abstract}
Determination of shear-wave (S-wave) velocity profiles is the first step in seismic hazard assessment of a town, because the dynamic parameters of local soil types are vital for seismic response analysis of a specific area in order to determine the local soil effect in a case of a seismic event for seismic risk analysis. S-wave velocity profiles have been determined for many areas within Györ. Extensive use of historical boring logs allowed for correlations and reasonable extrapolation of soil performance throughout the area. This has led to a pattern of soil layer distributions and delineates several different soil zones for Györ.
\end{abstract}

Keywords Local site effect - Shear-wave velocity profile - Dynamic properties of soils

\section{Introduction}

Research in earthquake hazard mitigation has focused on evaluating possible damage scenarios for different magnitude events (Luco et al. 2007; Committee on National Earthquake Resilience 2011). Although seismic events are rare in many places, they are characterized by high exposure and their economic and social effects cannot be neglected.

O. Kegyes-Brassai

kegyesbo@sze.hu

R. P. Ray

ray@sze.hu

P. Tildy

tildy.peter@mfgi.hu

1 Department of Structural and Geotechnical Engineering, Széchenyi István University, Egyetem tér 1., Györ 9026, Hungary

2 Department of Engineering Geophysics, Geological and Geophysical Institute of Hungary, Stefánia út 14., Budapest 1143, Hungary 
The vulnerability increases with extending urban areas. To reduce the potential damage, a comprehensive assessment of the seismic risk followed by a package of relevant remedial measures is needed.

Moderate seismicity does not necessarily equate to a moderate size of earthquakes: reports of major earthquakes often refer to heavy building damage and liquefaction. Hungary has experienced destructive earthquakes in the past; most significant was the event of 1763 in Komárom (Varga 2014) with estimated intensity of IX, and an intensity of VII-VIII in Györ according to European macroseismic scale (Grünthal 1998). Another large earthquake affecting Győr happened in 1850 with an intensity of VII. Although such events are very rare, their intensity is comparable to the major earthquakes such Northridge Earthquake (California 1994) with an intensity of IX according to modified Mercalli intensity scale (Southern California Earthquake Center 2001), being the second costliest disaster in US history after Hurricane Katrina (Martinez 2014).

The effects of topographic irregularities and alluvial basin geometry on ground motions can be significant. Ridges, canyons and ground slopes tend to shake differently from horizontal ground because seismic energy can be focused within their physical boundaries. Topographic effects were observed at a number of ridges in California during the 1971 San Fernando $(M L=6.4)$ earthquake (Trifunac and Hudson 1971), during earthquakes in Matsuzaki in Japan (Jibson 1987), and a small hill in Tarzana, California, during the 1994 Northridge Earthquake (Bouchon and Barker 1996). Many large cities are located on or near alluvial valleys; the effect of basin geometry on ground motion is of great interest. The softer deposited alluvial soils can trap body waves and cause some incident body waves to propagate through the alluvium as surface waves (Vidale and Helmberger 1988). These waves can produce stronger shaking and long durations.

The goal of the research is to integrate local site effects to previously determined seismic hazards (GeoRisk Earthquake Engineering Ltd. 2006). Therefore multichannel analysis of surface wave (MASW) measurements were performed and correlated to cone penetration test (CPT) measurements and soil boring data to estimate the dynamic properties of different soil types.

\section{Shear wave velocity as an indicator of the dynamic soil properties}

The stiffness of the soil at a site has a strong effect on the intensity of shaking delivered to the buildings at the surface. Variability in stiffness contributes to the large differences in ground motions over relatively short distances within sedimentary basins. Site effect studies are connected with the geodynamic characterization of the shallow layers, and can be grouped into three main categories (Bard 1997): experimental, numerical and empirical. In the absence of macroseismic data or earthquake records, several methods can be used for obtaining information about the soil response in an area of study. Generally, it is the shear wave ( $\mathrm{S}$-wave) velocity that is the best indicator of the response at a given site. This is because the major contributor to seismic action on a building is vertically propagating, horizontally polarized S-waves. To analyze site response, engineers use the relationship

$$
G_{\text {max }}=\rho_{\text {soil }} \cdot v_{s}^{2}=\frac{\gamma_{\text {soil }}}{g} \cdot v_{s}^{2},
$$

where $G_{\text {max }}$ is the shear modulus of the soil at low strain amplitudes, e.g., during a field seismic test $(\mathrm{kPa}), \rho_{\text {soil }}$ is the mass density of the soil, $v_{s}$ is the $\mathrm{S}$-wave velocity in soil $(\mathrm{m} / \mathrm{s})$, 
$\gamma_{\text {soil }}$ is the unit weight of the soil $\left(\mathrm{kN} / \mathrm{m}^{3}\right)$, and $g$ is the acceleration due to gravity $\approx 9.807 \mathrm{~m} / \mathrm{s}^{2}$.

The S-wave velocities can be measured via different methods (Szilvágyi 2012), such as borehole tests or MASWs. S-wave velocities will depend on soil density, grain size, confining stress, void ratio, pre-consolidation history, fabric, cementation, age, and method of deposition. Soil classification and correlation studies have been conducted by many researchers who have published values for dynamic properties of various soil formations based on specific structure (Table 1), placement (Table 2) or on age (Table 3). Many researchers have published their insights into the use of the 30-m profile approach to earthquake hazard assessment (Paoletti 2012; Kanli et al. 2006; Bauer et al. 2007).

$$
v_{s}=a \cdot D^{b} .
$$

Predictive equations, based on soil type, confining stress and deposition have also been published and appear in Tables 1 and 2. Researchers determine predictive equations for soil S-wave velocities to generate the required soils map for hazard analysis, that is, equations that could predict $S$-wave velocity as a function of the different factors mentioned above (Matsuoka et al. 2005). Table 3 provides the $\mathrm{P}$ and $\mathrm{S}$-wave values for different soil types for the first and second layer (later not presented).

For this study, ranges of values of $v_{s}$ were determined for each unit due to lateral and vertical variations in geological material types and their physical properties: a worst-case (based on the lower $v_{s}$ value) and a best-case (based on the higher value) presented in a later section.

Engineering codes have simplified these site effects into a single parameter: the average S-wave velocity in the upper $30 \mathrm{~m}$ at a site, $v_{s, 30}$ and soil classes are then assigned to different average values (Table 4). The codes then use the simplified profiles as input to determine response spectra for design. However, in many cases this is not enough and detailed S-wave velocity profiles are necessary for accurate ground motion modeling and application to building response analysis.

Table 1 Predictive equations for soil shear-wave velocities as a function of depth for soils in the Lower Hudson River Valley, New York after Nottis (2001)

\begin{tabular}{llllll}
\hline $\begin{array}{l}\text { Surficial } \\
\text { materials }\end{array}$ & $\begin{array}{l}\text { No. of } \\
\text { borings }\end{array}$ & $\begin{array}{l}\text { No. of } \\
\text { data } \\
\text { points }\end{array}$ & $\begin{array}{l}\text { Predictive equation } \\
\text { for } v_{s}(\mathrm{ft} / \mathrm{s})\end{array}$ & $\begin{array}{l}\text { Correlation } \\
\text { coefficient } r^{\mathrm{a}}\end{array}$ & $\begin{array}{l}\text { Recommended } \\
\text { depth range for } \\
\text { equation (ft) }\end{array}$ \\
\hline $\begin{array}{l}\text { Alluvium and } \\
\text { alluvial fans }\end{array}$ & 5 & 15 & $v_{s}=564.41 \times D^{0.1377}$ & 0.39 & $0-50$ \\
$\begin{array}{c}\text { Glacial kames } \\
\text { Glacial lake delta }\end{array}$ & 5 & 12 & $v_{s}=106.87 \times D^{0.664}$ & 0.97 & $0-60$ \\
$\begin{array}{c}\text { Glacial lake } \\
\text { sands }\end{array}$ & 5 & 11 & $v_{s}=520.02 \times D^{0.1623}$ & - & $0-30$ \\
$\begin{array}{c}\text { Glacial lake silts } \\
\text { and clays }\end{array}$ & 8 & 28 & $v_{s}=619.81 \times D^{0.1561}$ & - & $0-50$ \\
$\begin{array}{c}\text { Glacial outwash } \\
\text { sand and gravel }\end{array}$ & 5 & 27 & $v_{s}=301.52 \times D^{0.3225}$ & 0.45 & $0-100$ \\
$\begin{array}{c}\text { Glacial tilts } \\
\text { fand }\end{array}$ & 5 & 21 & $v_{s}=626.38 \times D^{0.2239}$ & 0.41 & $0-100$ \\
\hline
\end{tabular}

$D$ Depth in feet, $V s$ shear-wave velocity in feet/second, $r$ correlation coefficient

a No value is listed if equation was determined with only a subset of available data points 
Table 2 Stratigraphic units and range of $v_{s}$ after Perrin et al. (2010)

\begin{tabular}{llcll}
\hline Units & Description & $v_{s}(\min )(\mathrm{m} / \mathrm{s})$ & $v_{s}(\max )(\mathrm{m} / \mathrm{s})$ & Typical location \\
\hline I & Hydraulic fill & 50 & 150 & Aotea Quay \\
& Rock fill & 125 & 250 & Railway yards/Te Papa \\
& Other fill & 200 & 300 & Subdivisions \\
II & Holocene lake silt, swamp, peat & 50 & 200 & Thorndon (rare) \\
& Holocene sand/gravel, loose & 150 & 300 & Small stream channels \\
& Holocene sand/gravel, medium dense & 250 & 350 & \\
& Holocene sand/gravel, dense & 350 & 450 & \\
\hline
\end{tabular}

Table 3 Geomechanical properties for first $10 \mathrm{~m}$ of subsurface after Carvalho et al. (2009)

\begin{tabular}{|c|c|c|c|c|c|}
\hline \multirow[t]{2}{*}{ Geology } & \multirow[t]{2}{*}{ Profiles } & \multicolumn{2}{|c|}{ Velocity of first layer $(\mathrm{m} / \mathrm{s})$} & \multirow[t]{2}{*}{ VP1/VS1 } & \multirow{2}{*}{$\begin{array}{l}\text { Poisson's } \\
\text { ratio }\end{array}$} \\
\hline & & $\mathrm{P}$ wave & $\mathrm{S}$ wave & & \\
\hline \multirow[t]{2}{*}{ Holocenic deposits } & PN1 & 265 & 108 & 2.45 & 0.40 \\
\hline & ALV1 & 541 & 166 & 3.26 & 0.45 \\
\hline \multirow[t]{2}{*}{ Odiáxere gravels } & OD1 & 325 & 188 & 1.73 & 0.25 \\
\hline & FRA2 & 499 & 331 & 1.51 & 0.11 \\
\hline \multirow[t]{3}{*}{ Ludo formation } & LG2 & 285 & 189 & 1.51 & 0.11 \\
\hline & LGA1 & 365 & 250 & 1.46 & 0.06 \\
\hline & POR1 & 529 & 307 & 1.72 & 0.25 \\
\hline Mem Moniz fossiliferous limestones & TUN1 & 255 & 111 & 2.30 & 0.38 \\
\hline \multirow[t]{4}{*}{ Lagos-Portimäo formation $^{\mathrm{a}}$} & ALV2 & 249 & 113 & 2.20 & 0.37 \\
\hline & ALB1 & 311 & 193 & 1.61 & 0.19 \\
\hline & LG1 & 365 & 179 & 2.04 & 0.34 \\
\hline & FRA1 & 308 & 121 & 2.55 & 0.41 \\
\hline
\end{tabular}

Poisson's coefficient and $V_{\mathrm{P}} / V_{\mathrm{S}}$ ratios for shallow layers in western Algarve calculated from seismic refraction studies

${ }^{a}$ Carbonates, sandstones and silts

One goal of this research was to determine the S-wave profile for the different sites of Győr according to hydrogeological boring registers using MASW and CPT measurements.

\section{Data from literature and borings}

The geological map series of the Little Hungarian Plain offer a broad view about the formation and lithology of the area. Data concerning Gyor can be found on two sets of maps called Győr North and Györ South. The maps were determined from shallow borings (10 m deep) with a raster of approx. 1000-1500 m, a few small depth borings (30-40 m deep) and one middle deep borings (with $400 \mathrm{~m}$ depth) for each set of maps (Scharek and Tóth 1994). 
Table 4 Ground types of EC8 (European Committee for Standardization 2013)

\begin{tabular}{|c|c|c|}
\hline Types & Description of stratigraphic profile & $v_{s, 30}(\mathrm{~m} / \mathrm{s})$ \\
\hline A & $\begin{array}{l}\text { Rock or other rock-like geological formation, including at most } 5 \mathrm{~m} \text { of weaker } \\
\text { material at the surface }\end{array}$ & $>800$ \\
\hline $\mathrm{B}$ & $\begin{array}{l}\text { Deposits of very dense sand, gravel, or very stiff clay, at least several tens of } \\
\text { meters in thickness, characterized by a gradual increase of mechanical properties } \\
\text { with depth }\end{array}$ & $360-800$ \\
\hline $\mathrm{C}$ & $\begin{array}{l}\text { Deep deposits of dense or medium dense sand, gravel or stiff clay with thickness } \\
\text { from several tens to many hundreds of meters }\end{array}$ & $180-360$ \\
\hline $\mathrm{D}$ & $\begin{array}{l}\text { Deposits of loose-to-medium cohesionless soil (with or without some soft cohesive } \\
\text { layers), or of predominantly soft-to-firm cohesive soil }\end{array}$ & $<180$ \\
\hline $\mathrm{E}$ & $\begin{array}{l}\text { A soil profile consisting of a surface alluvium layer with } v_{s} \text { values of type C or D } \\
\text { and thickness varying between about } 5 \text { and } 20 \mathrm{~m} \text {, underlain by stiffer material } \\
\text { with } v_{s}>800 \mathrm{~m} / \mathrm{s}\end{array}$ & \\
\hline $\mathrm{S}_{1}$ & $\begin{array}{l}\text { Deposits consisting, or containing a layer at least } 10 \mathrm{~m} \text { thick, of soft clays/silts } \\
\text { with a high plasticity index }(\mathrm{PI}>40) \text { and high water content }\end{array}$ & $\begin{array}{l}<100 \\
\quad(\text { Indicative })\end{array}$ \\
\hline $\mathrm{S}_{2}$ & $\begin{array}{l}\text { Deposits of liquefiable soils, of sensitive clays, or any other soil profile not } \\
\text { included in types A-E or } S_{1}\end{array}$ & \\
\hline
\end{tabular}

The number of borings for the entire territory of Györ is about 28 shallow, and 6 small depth. Considering only the intensely built area, this number drops to 6 shallow and 1 small depth boring. To achieve a higher resolution, further data was necessary. The geological map series did offer a good overview about the wider area of Györ and the connections to the vicinity and the formation of sediments from different ages.

The thickness of quaternary deposits ranges between 10 and $50 \mathrm{~m}$ in Györ, only in the southern part it decreases to 5-10 m. The basement of Pannonian deposits is between 3000 and $5000 \mathrm{~m}$.

In order to increase the density of data and enhance the accuracy of soil profiles, further borings were needed. The task was to locate the possible sources for further data. The construction geotechnical database contains generally shallow borings that are much less than $30 \mathrm{~m}$ deep. The idea came to get permission from the North Transdanubian Environmental Protection and Water Management Inspectorate to use the soil profiles from the hydrogeological registers. On the territory of the investigated area, around 100 borings were available, from that 60 were picked for further study. The principle of selection was to cover adequately the study area with borings deeper than $30 \mathrm{~m}$.

The chosen 60 hydrogeological registers were drilled from 1954 to 2008, with a depth varying between 25 and $2155.7 \mathrm{~m}$. The depth and number of borings are presented in Table 5 .

The data was recorded by various drilling supervisors, with different descriptions of soil layers mainly focusing on water quality and quantity. One challenge was to identify the soil types to be able to compare and group them. The other challenge was related to the location of borings. The names of the streets changed in the last 50 years, factories disappeared, and the given coordinates were not exact enough and some did not correspond to

Table 5 Number and depth of borings concerning the hydrogeological registers

\begin{tabular}{llllllll}
\hline Depth (m) & $25-30$ & $30-50$ & $50-100$ & $100-200$ & $200-400$ & $400-700$ & 2155.7 \\
Number & 1 & 8 & 15 & 13 & 9 & 3 & 1 \\
\hline
\end{tabular}


Fig. 1 The compiled North and South Györ map (same section as Fig. 2) and sectioned around the city based on the layout map of geological observation sites (Scharek 1990, 1991)

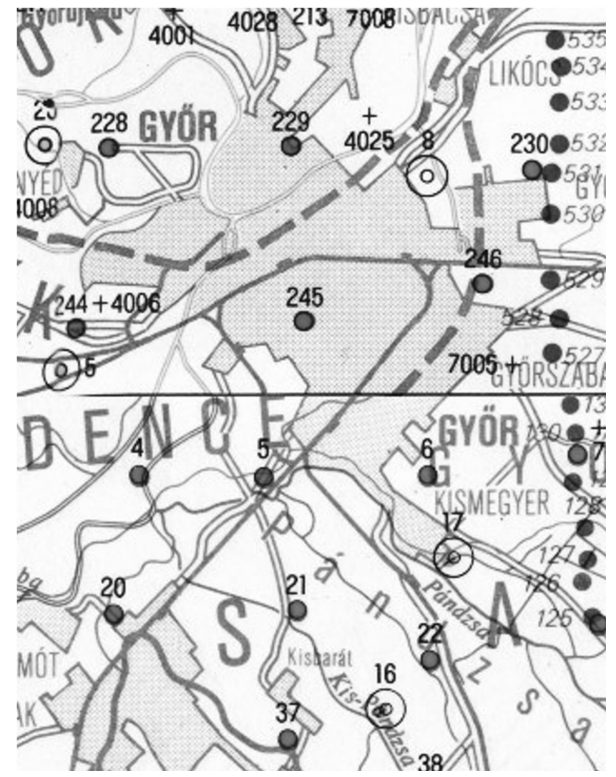

the site plans of the hydrogeological registers. After careful inspection and recalculation, the location of the borings are represented in Figs. 1 and 2.

The hydrogeological registers were mainly connected with water resources for different purposes: at Kiskút and Révfalu are those wells which supply the potable water for the city, the other wells support several industrial facilities. So dynamic properties were not a part of the boring logs. Another approach was needed to make better use of the data. We chose to perform MASW at selected sites, correlate the results to soil types found in the adjacent borings, then use that correlation to build profiles throughout the city area.

\section{MASW measurements and results}

The MASWs adopts the conventional seismic refraction mode of survey using an active seismic source such as hammers, weight drops, or explosives. The maximum depth of such investigation is usually $20-30 \mathrm{~m}$ depending on site, receivers and source applied and is determined by the longest wavelength of the surface waves generated by the impact power of the source. A greater impact with strong low-frequency components make it possible to detect a longer wavelength resulting in greater depth of penetration. Metallic plates placed on the ground surface are conventionally used for impact source locations (Park Seismic LLC 1990).

Similarly, low-frequency (vertical) geophones $(<4.5 \mathrm{~Hz})$ are recommended as receivers to obtain appropriate signals. The length of the receiver spread is usually limited to $50-100 \mathrm{~m}$, because of the typical power constraint of seismic sources. The length is directly related to longest wavelength detected and receiver-to-receiver spacing relates to the shortest wavelength detected. The spacing parameter also determines the thickness limit for the top layer. A shorter wavelength can identify a thinner layer as the top 


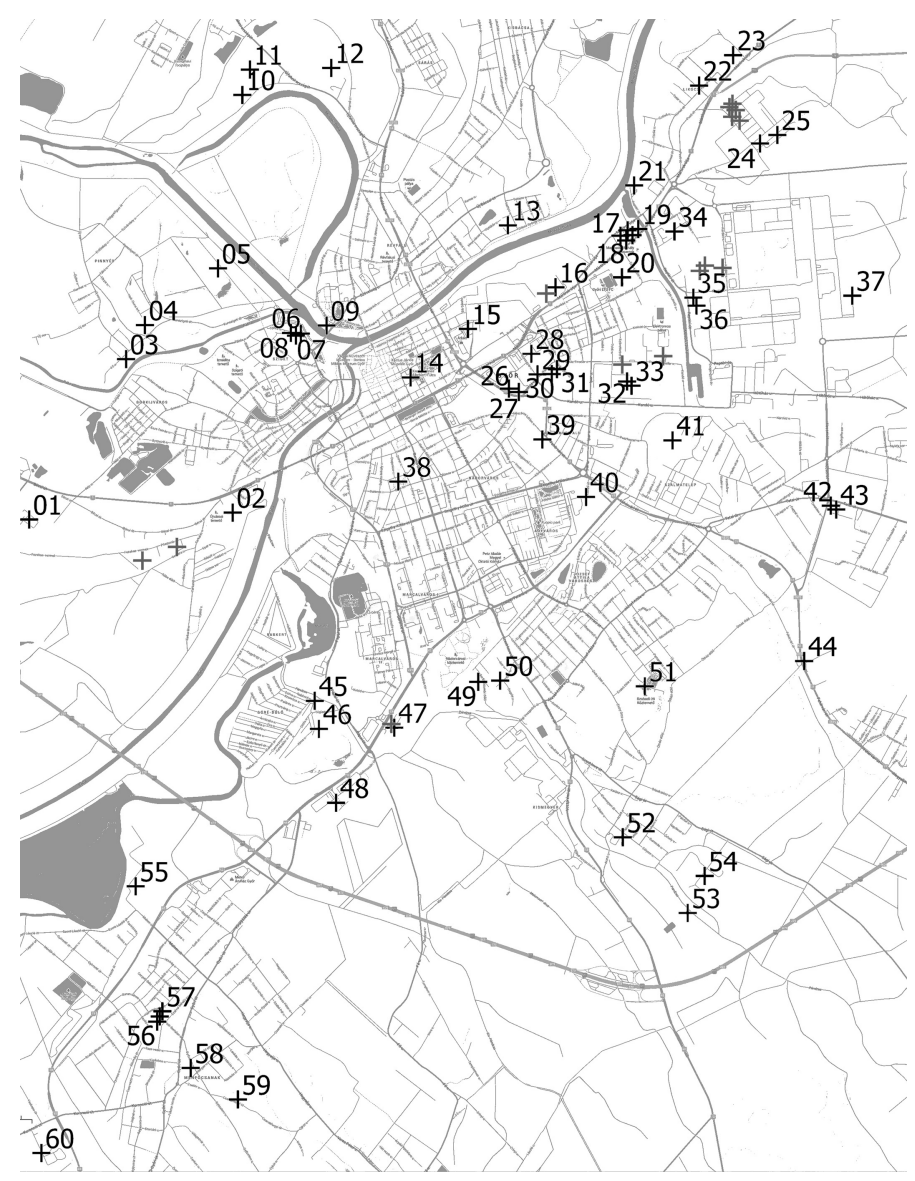

Fig. 2 Borings from hydrogeological registers marked on the map of Györ (same section as Fig. 1) numbered from 1 to 60 (numbered are deeper than $30 \mathrm{~m}$, MASW were performed at borings numbers $6-9$, $13,14,28,29,35,36,38,40,45-47,51$ and 53)

formation. The source and receiver spread distance is one of the variables that affect the horizontal resolution of the dispersion curve (Park et al. 2001).

Twenty four or more geophones are typically laid out in a linear array and connected to a multi-channel seismograph which collects data simultaneously from all geophones. Different types of waves are recorded through multichannel array. The dispersive nature of the waves is imaged through a wave-field transformation of seismic records by frequency wavenumber (f-k) or slowness-frequency (p-f) transform. From the dispersion image, a dispersion curve of the fundamental mode of Rayleigh waves is selected, which is then inverted for a 1D $v_{s}$ profile. Figure 3 shows a typical schematic of active MASW field survey.

The measurements in Györ were performed with DAQ Link3 instruments (manufacturer Seismic Source, US), which was guided with a field PC using a special data collecting software. Features of the instrument are presented in Table 6. 


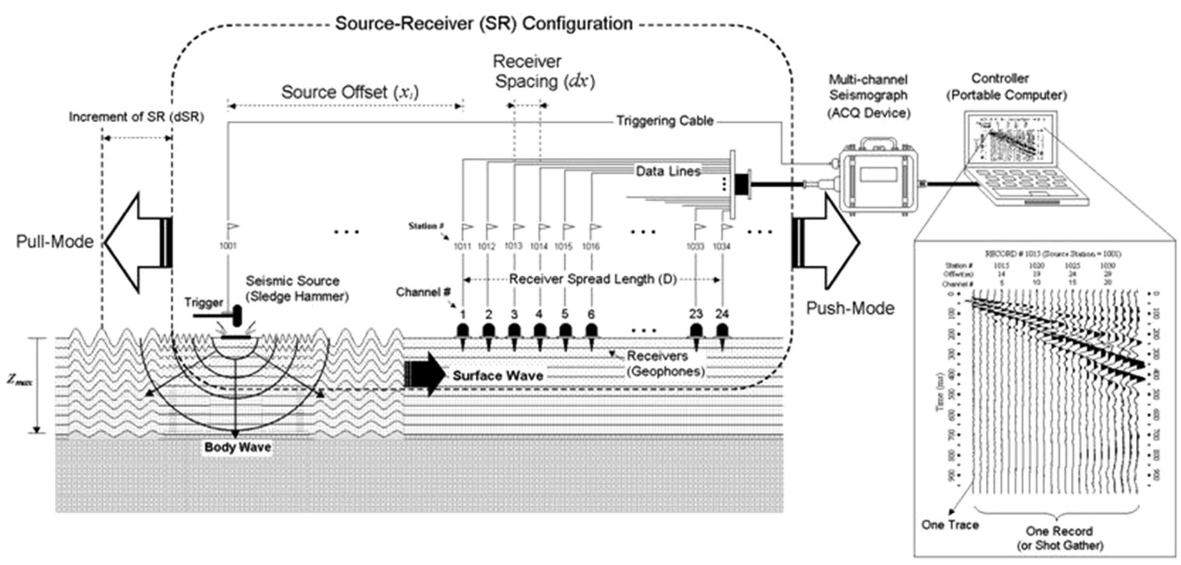

Fig. 3 Schematic of active MASW field survey (Park Seismic LLC 1990)

Table 6 Features and parameters of the applied instrument

Features of the instrument

Number of channels 24

Frequency range $0-15 \mathrm{kHz}$

ADC 24 bit Delta-Sigma

Sampling $62.5 \mu \mathrm{s}-16 \mathrm{~ms}$

Recording length 512-16,384 samples
Parameters of applied instrument

Sampling time $1 \mathrm{~ms}$
Sampling length 2000
Used geophones NC-2 with $2,3 \mathrm{~Hz}$ natural freq.
Interval of geophones $4 \mathrm{~m}$
Number of channels 24
Length of spreading $92 \mathrm{~m}$
Source hammer SR-II drop weight

A basic requirement concerning the choice of source, geophones and geometry of spreading was to enable the detecting of low frequency (i.e., long wavelength) components of the spectrum. These are important in order to determine the velocity parameters of the upper $30 \mathrm{~m}$ strata. Table 6 describes the parameters of instruments used to meet the requirements.

The SR-II is a specialized falling weight (Fig. 4) Seismic Source developed and manufactured by Eötvös Loránd Geophysical Institution, using the energy of $8 \mathrm{~g}$
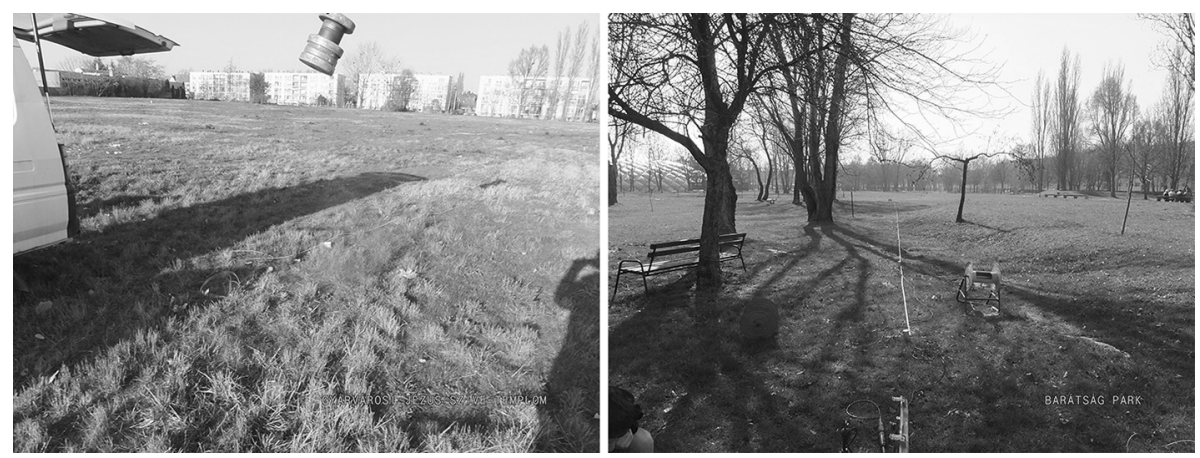

Fig. 4 The SR-II hammer $(L)$ and spacing of geophones $(R)$ 
Fig. 5 Field PC using a special data collecting software

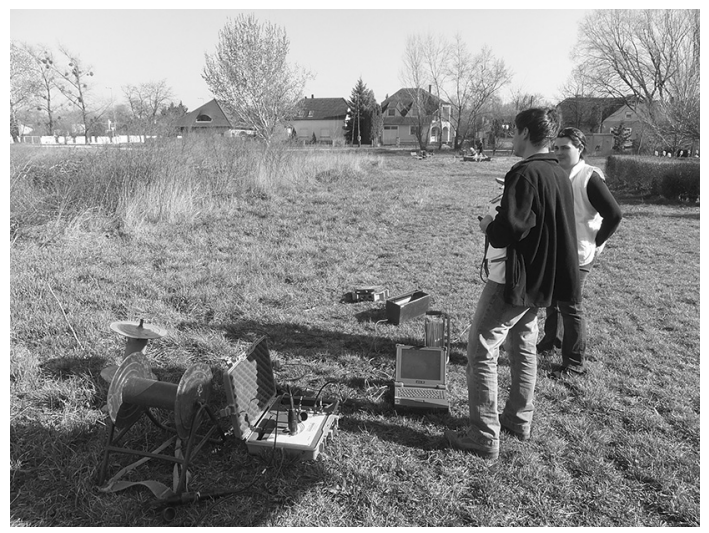

Fig. 6 Recording made with SR-II source

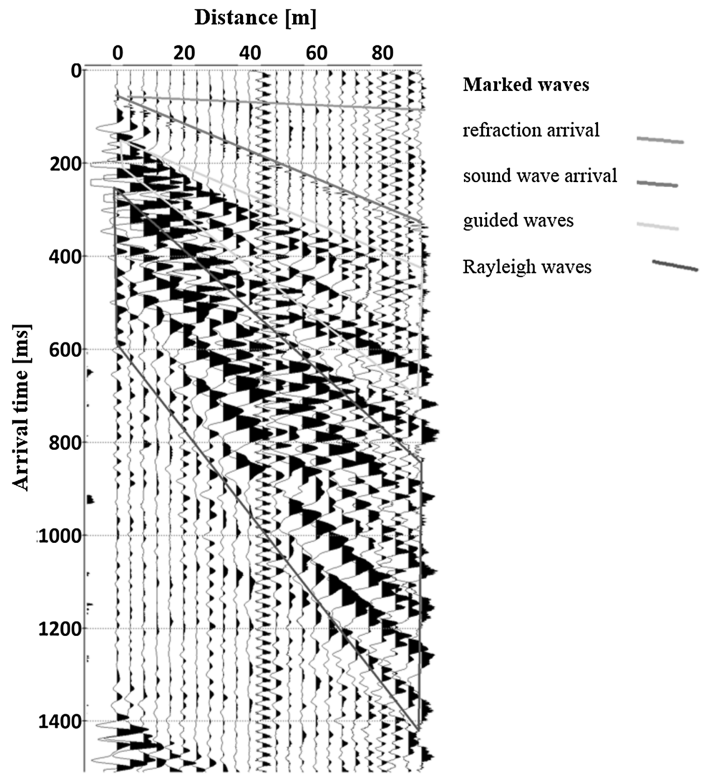

gunpowder filled cartridge for generating vibration (Kanli et al. 2006). Geophones were spaced at an interval of $4 \mathrm{~m}$ (Fig. 4).

The data analysis was carried out by the Russian program package called Deco Geophysical Software Company RadexPro (Fig. 5). The raw footage geometry and recording parameters were given first. After that, a few simple processing steps were required, which subsequently served to improve the signal-to-noise ratio (DC signal removal, tuning mute, summary). The program obtained the frequency-phase velocity image (Fig. 7) base on the phase-shift method, the dispersion curves were generated immediately on the image (Park et al. 1998).

Layer models were determined by the measured dispersion curves based on an inversion procedure according to Thomson-Haskell algorithm (Park et al. 1999). This means practically, that the software is varying layer parameters of the initial model (layer thickness, 
P-wave velocity, S-wave velocity, and bulk density) based on an algorithm, until the measured and calculated theoretical dispersion curve based on parameters fit properly.

A typical field recording can be seen on Fig. 6, frequency phase velocity images with marked dispersion curves are presented on Fig. 7. The white line shows the selected dispersion curves (fundamental and first mode). On Fig. 8 the calculated theoretical curves

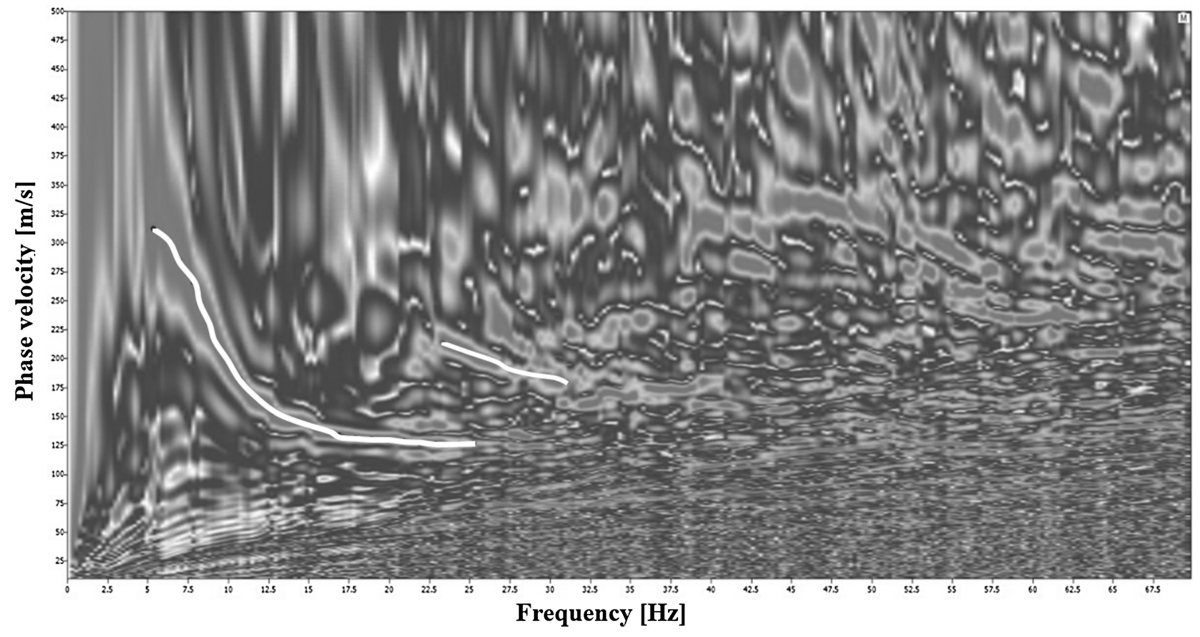

Fig. 7 Dispersion image of the recording based on phase shift

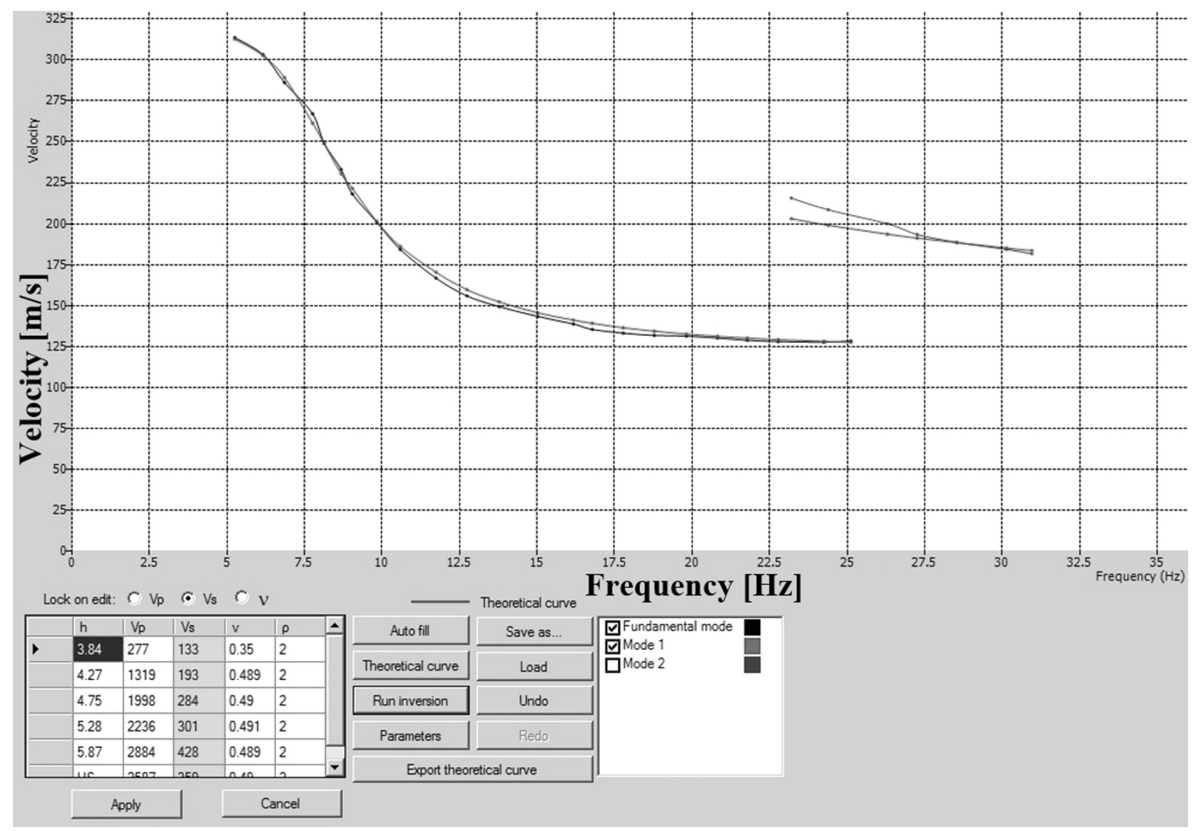

Fig. 8 The regression of the dispersion curve with RadexPro software 
from model parameters and the dispersion curves appear partially overlapped. The current model parameters appear in the lower left-hand table.

Average S-wave velocities were calculated for each site with the results shown in Table 7 and one of the plotted $v_{s}$ profiles can be seen in Fig. 9.

Table 7 MASW results about $v_{s, 30}$ and soil profile category

\begin{tabular}{llllllll}
\hline Names & EOV_Y & EOV_X & $\begin{array}{l}\text { Number } \\
\text { of layers }\end{array}$ & Depth $(\mathrm{m})$ & $\begin{array}{l}\text { Half-space } \\
\text { velocity }(\mathrm{m} / \mathrm{s})\end{array}$ & $\begin{array}{l}v_{s, 30} \\
(\mathrm{~m} / \mathrm{s})\end{array}$ & $\begin{array}{l}\text { Soil } \\
\text { categories }\end{array}$ \\
\hline G01 & 544,308 & 261,421 & 6 & 27.5 & 391 & 286 & $\mathrm{C}$ \\
G02 & 543,048 & 261,704 & 6 & 25.3 & 461 & 297 & $\mathrm{C}$ \\
G03 & 544,744 & 262,852 & 6 & 26.4 & 365 & 292 & C \\
G04 & 545,477 & 261,477 & 6 & 26.4 & 426 & 323 & C \\
G05 & 544,000 & 260,260 & 6 & 24.2 & 405 & 320 & C \\
G06 & 543,661 & 258,115 & 6 & 19.8 & 344 & 304 & C \\
G07 & 546,539 & 258,250 & 6 & 30.8 & 521 & 323 & C \\
G08 & 545,861 & 260,003 & 6 & 18.7 & 336 & 294 & C \\
G09 & 546,931 & 261,918 & 6 & 28.6 & 400 & 311 & C \\
G10 & 543,290 & 261,956 & 5 & 20.9 & 326 & 270 & C \\
G11 & 546,803 & 256,010 & 7 & 33.0 & 645 & 467 & B \\
\hline
\end{tabular}

Fig. 9 The $v_{s}$ soil profile from MASW measurement (at Dunakapu Square)

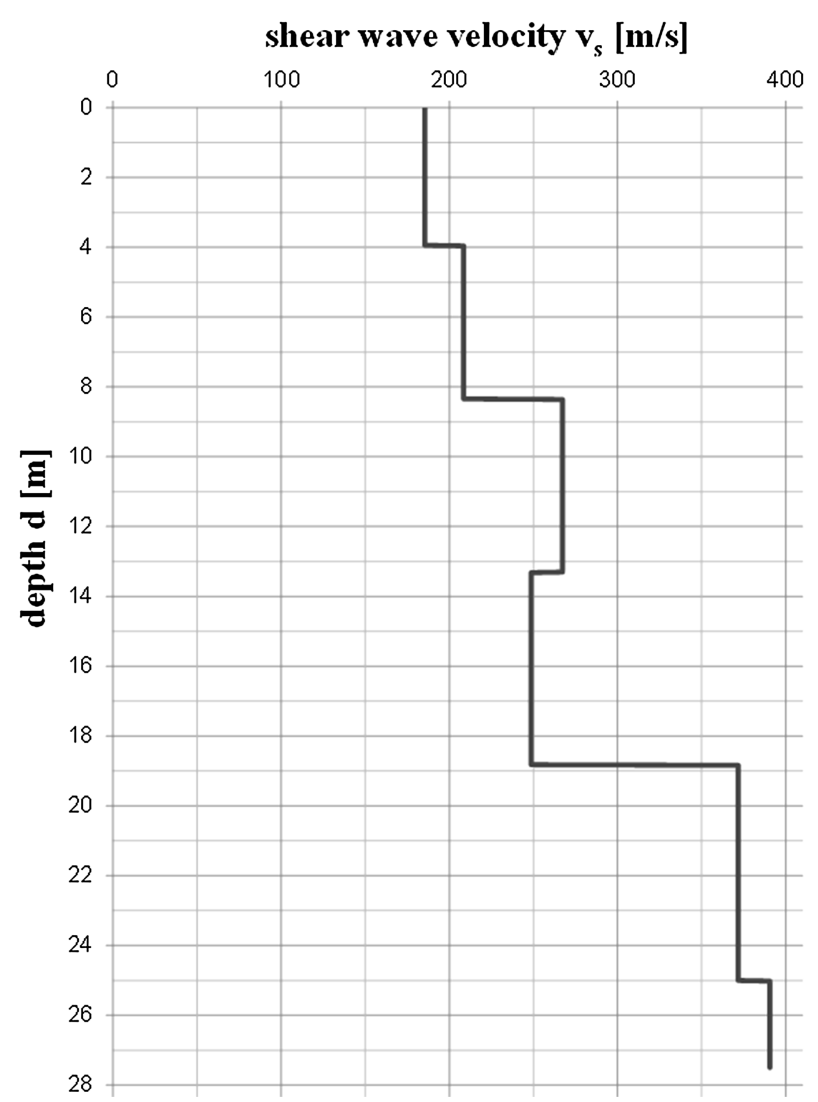




\section{CPT measurements and results}

The cone penetration test involves advancing an instrumented cone penetrometer into the ground and measuring the cone tip resistance $\left(q_{t}\right)$ and sleeve friction $\left(f_{s}\right)$ at selected intervals (typically 1-5 cm). CPT systems used for geotechnical site investigation are the conventional CPT, the Piezo-CPT (CPTu), and the seismic CPT (SCPT or SCPTu). The SCPT is performed in the same manner as the CPT with the addition of a geophone or accelerometer located in the CPT tip. The $v_{s}$ is measured at selected intervals (typically $1-$ $2 \mathrm{~m}$ ) by striking a steel or wood beam pressed firmly against the ground and calculated based on the difference in travel time of the S-wave between the source and the geophone at two consecutive depth positions. CPTu incorporates a pore pressure transducer to measure the dynamic pore water pressure located behind the cone tip allowing the correction of the tip resistance due to pore pressures acting on unequal areas of the cone, and can be calculated by

$$
q_{t}=q_{c}+\left(1+a_{n}\right) \cdot u_{2},
$$

where $\mathrm{q}_{\mathrm{c}}$ is the measured tip resistance and $\mathrm{a}_{\mathrm{n}}$ is the net area ratio.

The CPT does not retrieve actual soil samples for classification. Soil classification estimation is typically based in interpreted soil behavior type (SBT) presented in Fig. 10 (Robertson and Cabal 2012).

S-wave velocity can be obtained by the equation based on Robertson and Cabal:

$$
v_{s}=\left(\alpha_{v s}\left(q_{t}-\sigma_{v}\right) / p_{a}\right)^{0.5}(\mathrm{~m} / \mathrm{s}),
$$

where

$$
\alpha_{v s}=10^{\left(0.55 \cdot I_{c}+1.68\right)},
$$

and the vertical total stress is $\sigma_{v}$, atmospheric pressure is $p_{a}=100 \mathrm{kPa}$. The soil behavior type index can be calculated as

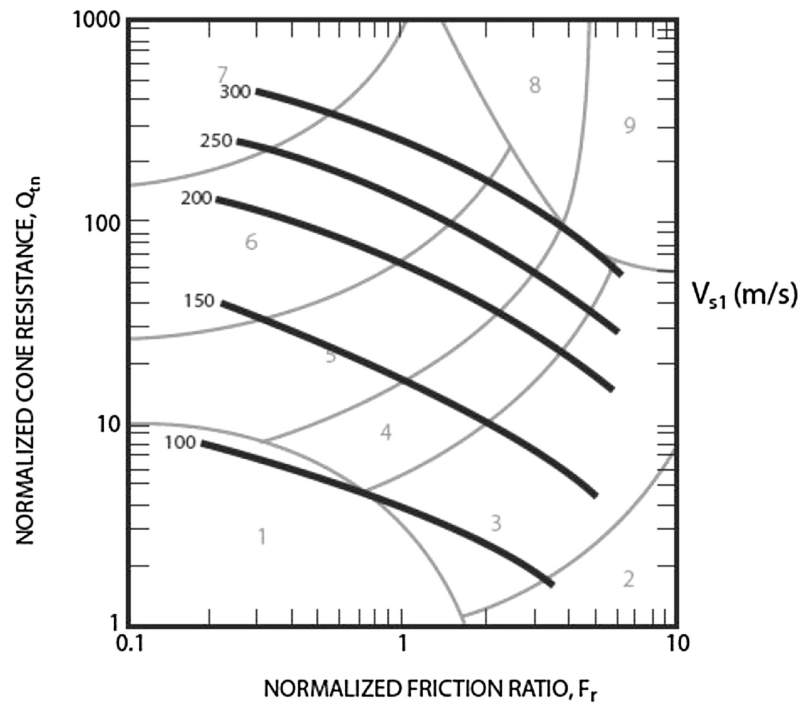

Fig. 10 Normalized CPT soil behavior type (SBT) chart (Robertson and Cabal 2012) 


$$
I_{c}=\left\lceil\left(3.47-\log Q_{t}\right)^{2}+\left(\log F_{r}+1.22\right)^{2}\right\rceil^{0.5},
$$

where the dimensionless normalized cone penetration resistance is

$$
Q_{t}=\left(q_{t}-\sigma_{v 0}\right) / \sigma_{v 0}^{\prime},
$$

and the normalized friction ratio $(\%)$ is

$$
F_{r}=\left(f_{s} /\left(q_{t}-\sigma_{v 0}\right)\right) \times 100 \%,
$$

where $f_{s}$ is the sleeve friction, $q_{t}$ is the corrected tip resistance and $\sigma_{v 0}$ is the vertical stress at depth of CPT test (Eq. 3) and $\sigma_{v 0}^{\prime}$ is the effective overburden pressure.

Raw CPT data were contributed by geotechnical companies at four locations, which ensured the verification of the results. The first step was to plot the cone resistance, sleeve friction, friction ratio and pore pressure illustrated in Fig. 11. The soil layers were identified based on SBT chart of Robertson and Cabal. S-wave velocities were calculated and average $v_{s}$ values were determined for each soil layer.

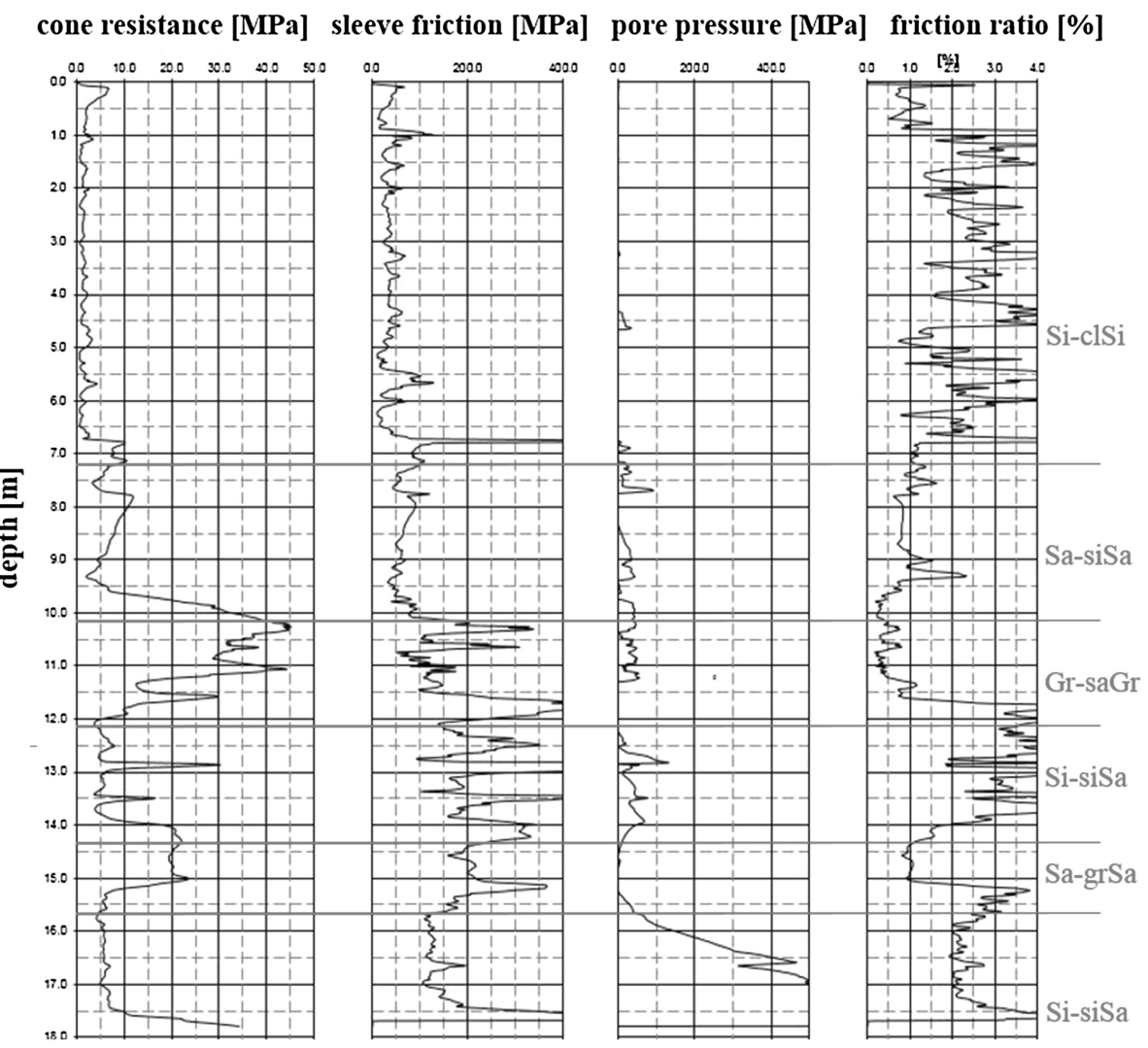

Fig. 11 Plot of cone resistance, sleeve friction, pore pressure and friction ratio with identified soil layers based on SBT chart (at Dunakapu Square, boring number 14) 


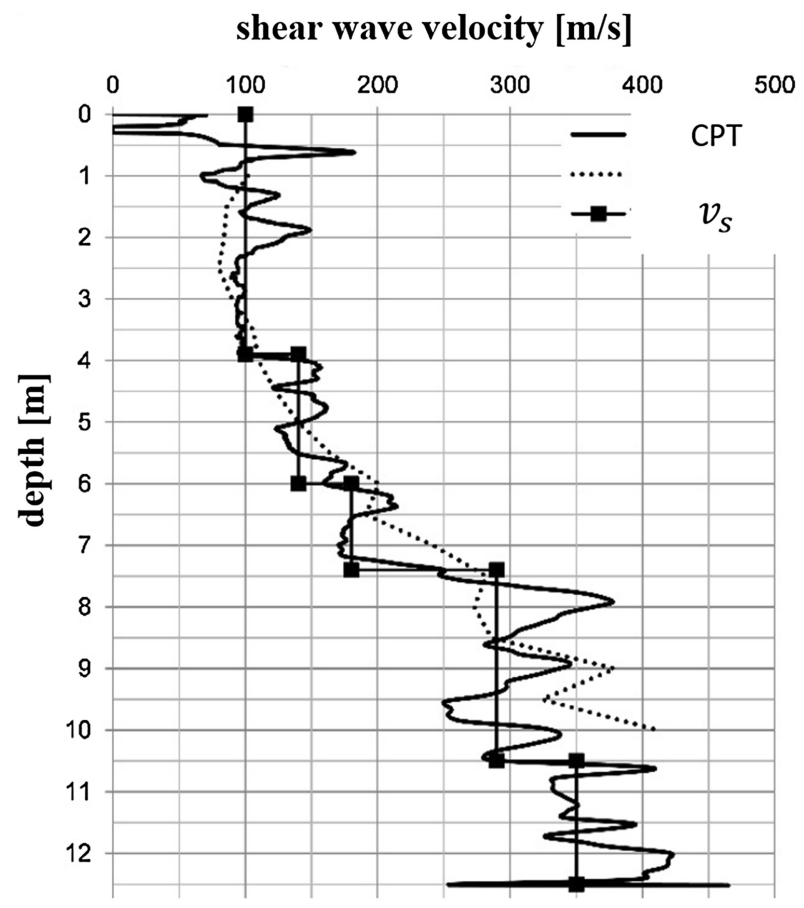

Fig. 12 Average $v_{s}$ values for soil layers

Figure 12 shows the $\mathrm{S}$-wave velocities. The $v_{s}$ is usually increasing with depth, so correction of the $v_{s}$ values should be done according to

$$
v_{s 1}=v_{s}\left(\frac{p_{a}}{\sigma_{v 0}^{\prime}}\right)^{0.25} \text {. }
$$

This correction results in the increase of values in the upper 8-10 $\mathrm{m}$ of strata, while below that a slight decrease of the values of $v_{s}$. Comparison of the two velocity values is shown in Fig. 13a, b.

Taking into account the usual ground water level the $v_{s}$ values were defined for several cases: where the ground water level was 2, 3 and $4 \mathrm{~m}$ (Cs. Deseö 1989). The difference between $v_{s, 30}$ values based on different ground water levels is less than $1 \%$, and has no significant influence on the average S-wave velocity [Fig. 13, compare all of (a) to all of (b)], so for further calculations the ground water level was assumed to be $3 \mathrm{~m}$.

\section{MASW and CPT correlation}

MASW results and CPT results were correlated at four locations: Dunakapu Square in Downtown, on the two sides of Jedlik Bridge in Sziget and Révfalu city districts, and in Gyárváros. For the completed depth of CPT, average S-wave velocities were calculated and compared to the average S-wave velocities obtained from MASW measurements for the same depth. Compared to each other it can be clearly seen a quite good match with a difference ranging between 0.35 and $5.26 \%$, except one case, with a difference of 

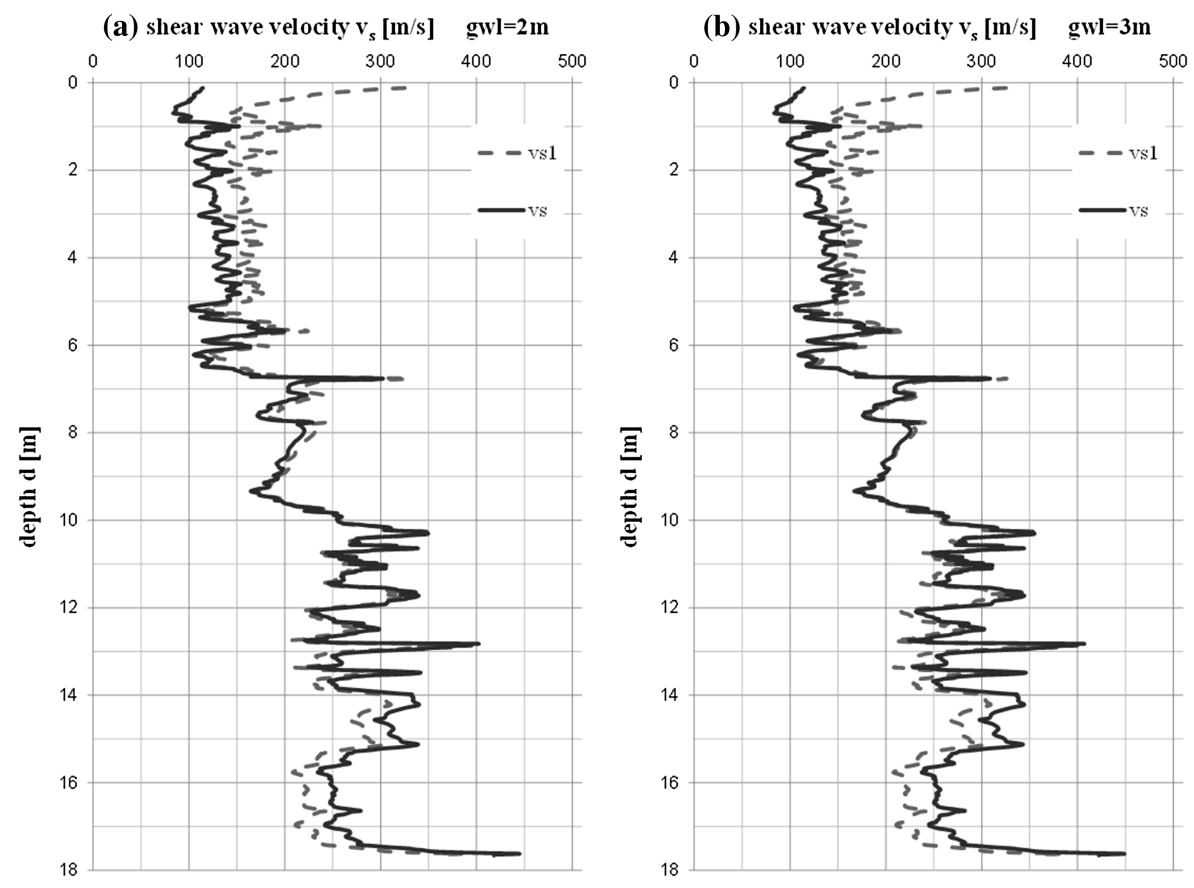

Fig. 13 Plotted $v_{s}$ and $v_{s 1}$ taking into account different ground water level (boring number 14)

$18.04 \%$, that can be explained by a layer of higher S-wave velocities, that was partially examined by CPT measurements. Figure 14 presents one of the results from the correlation.

\section{Identification of $v_{s}$ properties and determination of $v_{s, 30}$}

The $v_{s}$ values for each soil type were defined from MASW measurements. First, the approximate $v_{s}$ range determination and $v_{s, 30}$ calculations for the 60 borings required the reorganization of previously delineated groupings and categorization of soil types, because on one hand it was obvious that previously determined soil layers could have similar $\mathrm{S}$-wave velocities, and on the other hand differences were found based on more detailed categorization. The following soil categories were defined: Ss (sandstone), Cls (claystone), clay $(\mathrm{Cl})$, silt $(\mathrm{Si})$, clayey sand (clSa), silty sand ( $\mathrm{siSa})$, sand ( $\mathrm{Sa})$, gravelly sand ( $\mathrm{grSa})$, sandy gravel ( $\mathrm{saGr}$ ), gravel (Gr), silty clay $(\mathrm{siCl})$, sandy clay $(\mathrm{saCl})$, and two stiffer soil types found in Kismegyer with higher S-wave velocities. CPT results were used only for validation purposes.

Predictive equations were defined by finding a regression for each MASW measured $v_{s}$ profile in the following form:

$$
v_{s, i}=a \cdot D^{b},
$$

where $D$ is depth below ground surface $(\mathrm{m}), a$ can be interpreted as a basic $v_{s}$ value for each soil category, and $b$ is the depth correlation coefficient. Minimizing the error by 
Belváros [MASW: Színház; CPT: Dunakapu tér]

soil type: C

shear wave velocity $\mathrm{v}_{\mathrm{s}}[\mathrm{m} / \mathrm{s}]$

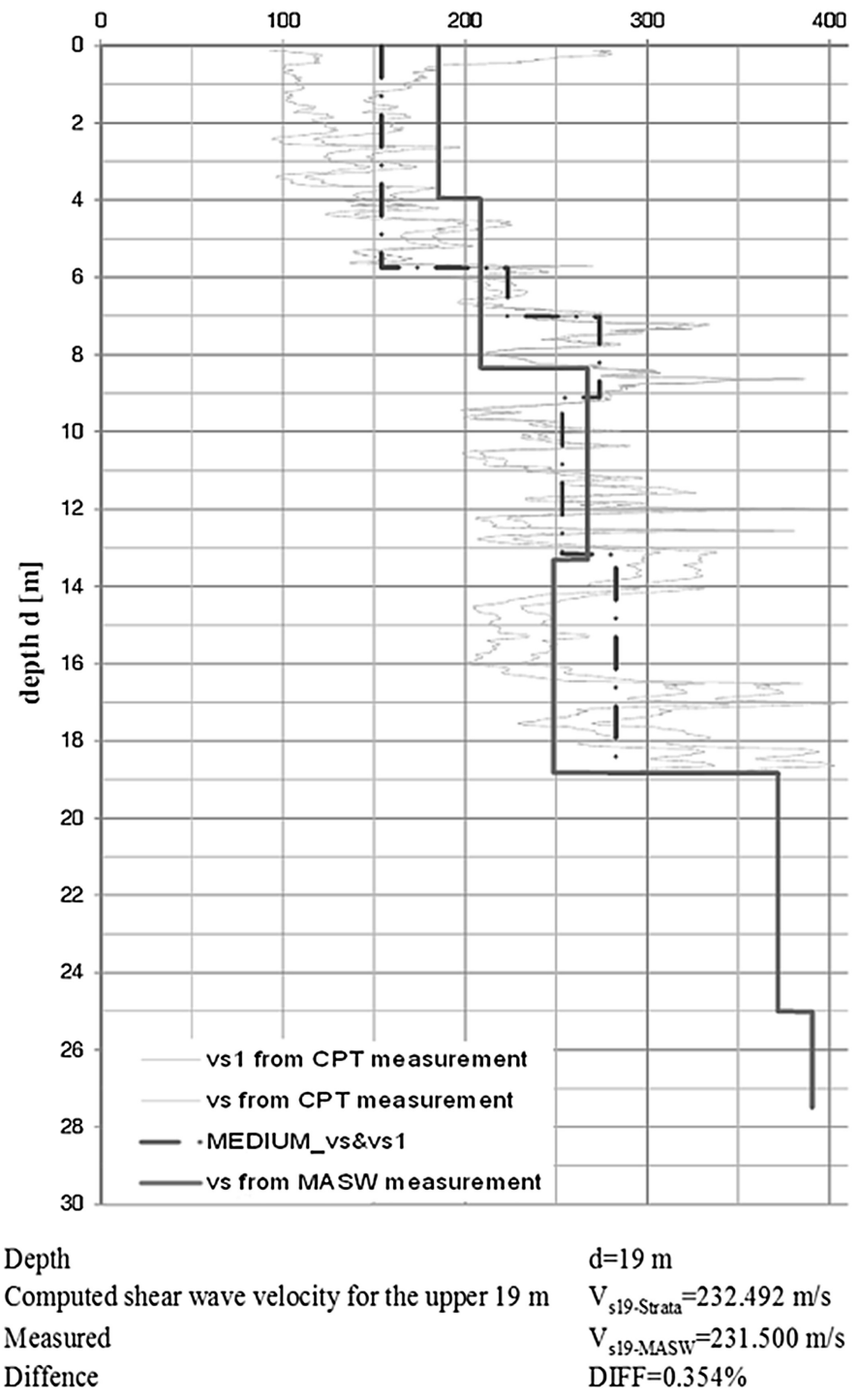

Fig. 14 Correlated result of CPT and MASW measurements (boring number 14)

varying $a$ and $b$ values of the equation, the computed $v_{s}$ values and the measured values could be matched accurately (Fig. 15) (Kegyes-Brassai 2015).

For each layer noted on MASW recordings, an average S-wave velocity was determined, and the depth of the mid-point of each layer was also recorded. The predictive equations for each kind of surficial material were then created by plotting the mid-point depth values and corresponding S-wave velocity values from the appropriate MASW record on a graph, and then best-fitting the Eq. 10. Equations of this form are usually used to relate $\mathrm{S}$-wave velocity and depth. Correlation coefficients for the determined equations 


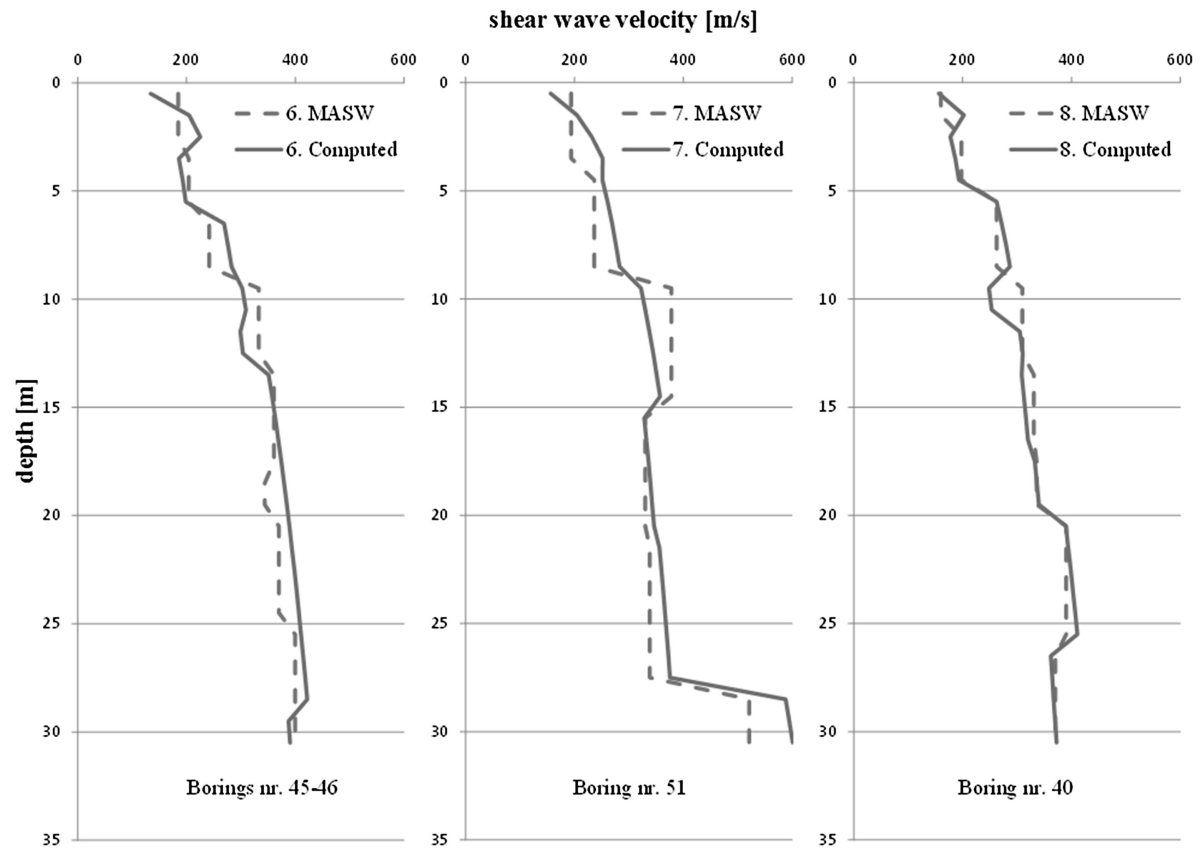

Fig. 15 Correlation of computed and measured $v_{s}$ profiles (at boring numbers 45-46, 51 and 40)

Table 8 Predictive equations for different soil types in Györ

\begin{tabular}{lllll}
\hline Based on MASW measurements & & & \multicolumn{2}{l}{ Based on literature and optimization } \\
\cline { 5 - 5 } Soil types & Predictive equations & & Soil types & Predictive equations \\
\hline $\mathrm{Cl}$ & $v_{s, i}=190 \times D^{0.1858}$ & & $\mathrm{Ss}$ & $v_{s, i}=250 \times D^{0.3050}$ \\
$\mathrm{Si}$ & $v_{s, i}=180 \times D^{0.1181}$ & & $\mathrm{Cls}$ & $v_{s, i}=200 \times D^{0.2700}$ \\
$\mathrm{siSa}$ & $v_{s, i}=155 \times D^{0.2087}$ & & $\mathrm{clSa}$ & $v_{s, i}=185 \times D^{0.2136}$ \\
$\mathrm{Sa}$ & $v_{s, i}=185 \times D^{0.2186}$ & & $\mathrm{Gr}$ & $v_{s, i}=180 \times D^{0.2200}$ \\
$\mathrm{grSa}$ & $v_{s, i}=155 \times D^{0.1461}$ & & saGr & $v_{s, i}=195 \times D^{0.1900}$ \\
$\mathrm{siCl}$ & $v_{s, i}=185 \times D^{0.2046}$ & & stiffCl & $v_{s, i}=200 \times D^{0.3219}$ \\
$\mathrm{saCl}$ & $v_{s, i}=185 \times D^{0.2463}$ & & stiffclSa & $v_{s, i}=195 \times D^{0.3388}$ \\
\hline
\end{tabular}

ranged from $r=0.18$ to 0.24 based on our measurements and in case of less data based on literature from $\mathrm{r}=0.19$ to 0.34 , presented in Table 8 .

Some soil types were underrepresented in MASW measurements, in those cases the values for equation were obtained by literature and optimization. S-wave velocity intervals were defined for each soil type varying with depth by $5 \mathrm{~m}$ steps (Table 9) (Kegyes-Brassai 2015).

Calculation of $v_{s, 30}$ for each boring were performed, based on three different methods: first using the determined $v_{s}$ intervals for each soil type based on the Table 7, then applying the values of predictive equations, finally with the help of Hardin and Black's (1968) 
Table 9 Shear-wave velocity intervals differentiated by depth for soil types (Fig. 17) in Györ

\begin{tabular}{|c|c|c|c|c|c|c|c|c|c|c|c|c|c|c|c|c|c|c|}
\hline \multirow[t]{2}{*}{ Depth [m] } & \multicolumn{6}{|c|}{ MED $v_{s}[\mathrm{~m} / \mathrm{s}]$} & \multicolumn{6}{|c|}{ MIN vs $[\mathrm{m} / \mathrm{s}]$} & \multicolumn{6}{|c|}{$\operatorname{MAX} \mathrm{vs}[\mathrm{m} / \mathrm{s}]$} \\
\hline & & 169.79 & 178.69 & & 183.09 & 162.89 & & 131.44 & 140.07 & & 131.44 & 134.13 & & 204.00 & 193.09 & & 215.58 & 201.31 \\
\hline \multirow[b]{4}{*}{$1-5$} & & 19093 & 23300 & & 185.86 & 20779 & & 15980 & 20215 & & 163.31 & 200.57 & & 22273 & 25704 & & 20840 & 21500 \\
\hline & & 19436 & 21211 & & & & & 19436 & 16704 & & & & & 23649 & 25127 & & & \\
\hline & & & & & 19294 & 23583 & & & & & 183.68 & 21215 & & & & & 20220 & 25950 \\
\hline & & 20381 & 25609 & & 191.80 & 192.67 & & 18706 & 16000 & & 159.80 & 15597 & & 27082 & 32459 & & 215.58 & 251.86 \\
\hline \multirow[b]{5}{*}{$5-10$} & & 19306 & 21923 & & 321.33 & 275.30 & & 16922 & 19883 & & 30966 & 24795 & & 21043 & 28595 & & 333.00 & 302.66 \\
\hline & & 22010 & 276.33 & & 20840 & 22435 & & 21834 & 26857 & & 20840 & 22015 & & 22273 & 28741 & & 20840 & 22837 \\
\hline & & 23885 & 27387 & & 324.49 & 29574 & & 236.49 & 26082 & & 324.49 & 29223 & & 24200 & 28280 & & 32449 & 29926 \\
\hline & & 26329 & 28274 & & 22079 & 27450 & & 26161 & 26221 & & 18368 & 221.22 & & 26620 & 29323 & & 26723 & 29909 \\
\hline & & 31622 & 38109 & & 345.64 & 319.17 & & 270.82 & 34625 & & 329.40 & 313.37 & & 38432 & 41286 & & 378.12 & 32207 \\
\hline \multirow[b]{5}{*}{$10-15$} & & 23565 & 22398 & & 292.98 & 275.04 & & 21043 & 21853 & & 26463 & 253.18 & & 25247 & 22908 & & 33300 & 30935 \\
\hline & & & & & 264.69 & 26204 & & & & & 248.55 & 24479 & & & & & 309.66 & 30966 \\
\hline & & 31520 & 29406 & & 324.49 & 31159 & & 24855 & 24686 & & 324.49 & 30572 & & 33300 & 312.30 & & 32449 & 31733 \\
\hline & & 284.93 & 305.51 & & 26723 & 312.45 & & 261.61 & 294.12 & & 26723 & 304.83 & & 33377 & 319.73 & & 26723 & 319.74 \\
\hline & & 428.67 & 453.03 & & 359.21 & 345.87 & & 38432 & 426.38 & & 329.40 & 330.11 & & 463.43 & 473.08 & & 378.12 & 357.42 \\
\hline \multirow[b]{5}{*}{$15-20$} & & 25247 & 23238 & & 26463 & 27817 & & 25247 & 23132 & & 26463 & 27462 & & 25247 & 23344 & & 26463 & 28166 \\
\hline & & 381.49 & $\begin{array}{lll}354 & 19\end{array}$ & & 538.58 & 52398 & & 371.71 & 35419 & & 538.58 & 51432 & & 391.27 & 35419 & & 538.58 & 53353 \\
\hline & & 31827 & 32874 & & 24932 & 25097 & & 31205 & 31620 & & 24855 & 24686 & & 330.72 & 33971 & & 25028 & 25407 \\
\hline & & 34364 & 33425 & & 329.97 & 33573 & & 32640 & 32412 & & 329.97 & 328.24 & & 37852 & 33971 & & 329.97 & 34288 \\
\hline & & 45055 & 486.62 & & 370.98 & 37566 & & 42477 & 48334 & & 34400 & 36334 & & 46343 & 49317 & & $\begin{array}{lll}443 & 05\end{array}$ & 384.47 \\
\hline & & & & & & & & & & & & & & & & & & \\
\hline \multirow{4}{*}{$20-25$} & & 38149 & 35808 & & 538.58 & 55138 & & 37171 & 35808 & & 538.58 & 54264 & & 39127 & 35808 & & 53858 & 56003 \\
\hline & & $\begin{array}{l}33735 \\
\end{array}$ & 34176 & & 364.84 & 36140 & & 31205 & 33602 & & 33841 & 35631 & & 35000 & 34657 & & 39127 & 36639 \\
\hline & & 36925 & 34969 & & 41752 & 353.16 & & 326.40 & 34320 & & 329.97 & $346 \quad 15$ & & 37852 & 35595 & & 461.29 & 35808 \\
\hline & & 656.53 & 55638 & & 39672 & 39812 & & 65653 & 55264 & & 37000 & 38924 & & 65653 & 56011 & & 37000 & 38924 \\
\hline & & & & & & & & & & & & & & & & & & \\
\hline \multirow[b]{4}{*}{$25-30$} & & 39291 & 38098 & & & & & 39055 & 37559 & & & & & 40000 & 38774 & & & \\
\hline & & 36222 & 35221 & & 365.81 & 375,10 & & 36000 & 346.85 & & 338.41 & 36953 & & 370.00 & 356.37 & & 39127 & 38122 \\
\hline & & 36947 & 36500 & & & & & $\begin{array}{lll}365 & 19\end{array}$ & 358.88 & & & & & 37000 & 36974 & & & \\
\hline & & $\begin{array}{lll}617 & 87\end{array}$ & $\begin{array}{llll}584 & 07\end{array}$ & & 416.12 & 41729 & & $\begin{array}{lll}521 & 23\end{array}$ & 56737 & & 39000 & 41073 & & 65653 & 59462 & & 43000 & 42574 \\
\hline
\end{tabular}

formula (Eq. 11). In terms of its maximum value in small strain ranges, $G_{\max }$ will depend on several factors, such as plasticity index of the soil, over consolidation ratio (OCR), normal stress, void ratio, etc.

$$
G_{\max }=625 \cdot \frac{O C R^{K}}{0.3+0.7 e^{2}} \cdot p_{a}^{0.5} \cdot \sigma^{0.5}
$$

where OCR is the over consolidation ratio, $\mathrm{K}$ is the exponent of OCR, $\sigma$ is the normal stress, $e$ is the void ratio. Value of $v_{s}$ can then be obtained by

$$
v_{s}=\left(\frac{G_{\max }}{\rho}\right)^{0.5} \text {, }
$$

where $\rho$ is density obtained from the total unit weight of the soil divided by gravity $\left(9.81 \mathrm{~m} / \mathrm{s}^{2}\right)$.

The values of the Table 9 were used to determine the $v_{s}$ profile for the given 60 borings and to calculate $v_{s, 30}$ values in each case. Average $S$-wave velocity for the upper $30 \mathrm{~m}$ were defined based on minimum, medium and maximum values of the $v_{s}$ intervals, the predictive equation, and Hardin and Black's formula (Fig. 16).

Both time-average and weighted-average method (Wair et al. 2012) was used in each calculation to determine $v_{s, 30}$ values. A comparison was made between the computed average S-wave velocities computed, and reported field measurements of S-wave velocities in surficial materials. The match was obtained by weighted-average of the medium values of the S-wave velocity intervals. The error, i.e., the average of the differences at sites, 

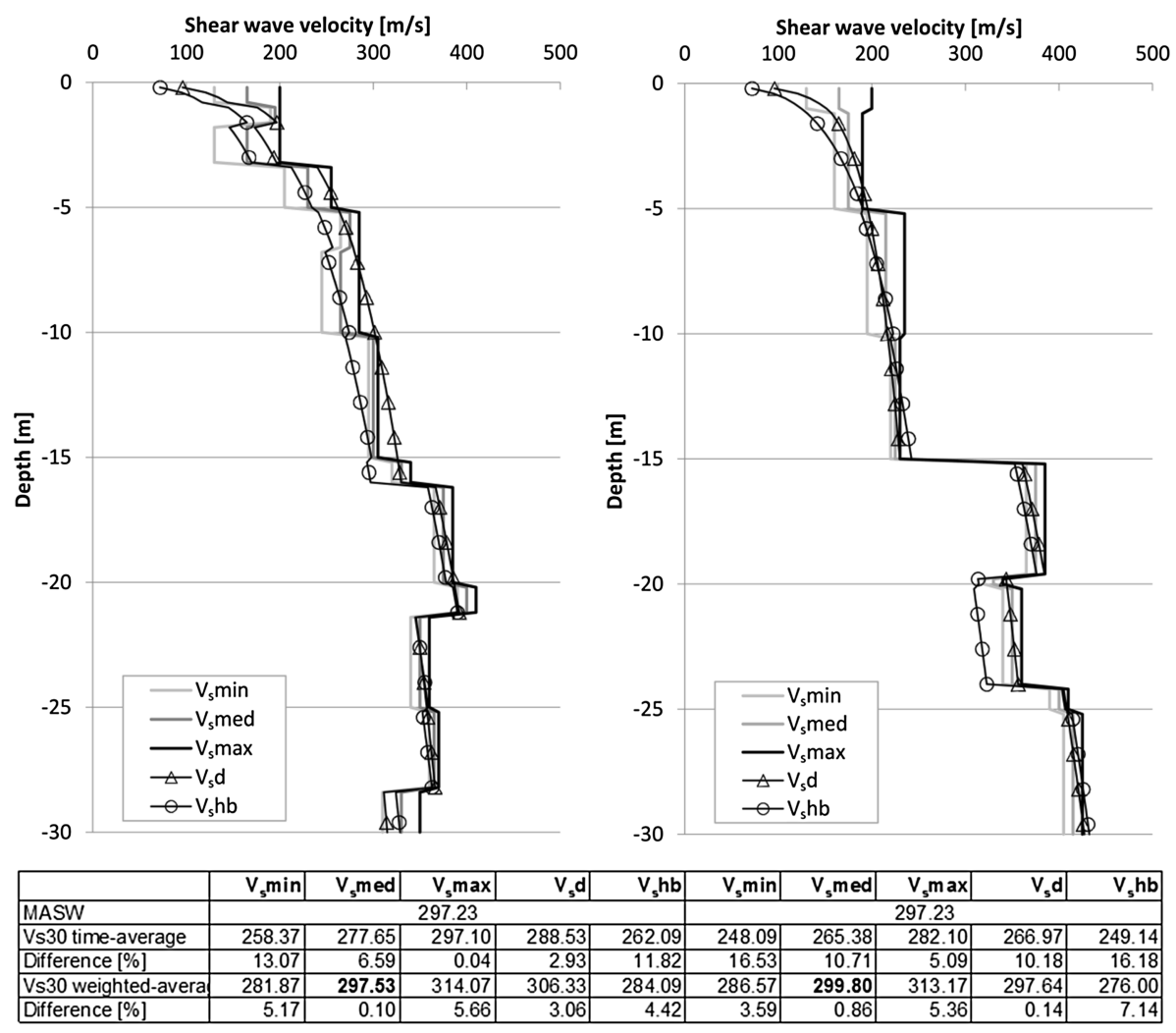

Fig. 16 Shear-wave velocity profiles and comparison with measured data at boring numbers 6 and 7

where MASW data were available, is $0.64 \%$, which offers an appropriate accuracy for further calculations. The determined $v_{s}$ intervals can be used in response analysis.

\section{Zonation and mapping}

Previous groupings based on strata and former geomorphological studies proved to be adequate, reassignment of only one or two borings were needed based on $v_{s, 30}$. The final grouping is presented in Fig. 17, soil profiles are numbered from I to XV. In case of four profiles only one boring formed the basis of examination, and in three cases measured data is not available.

The reliability of the SPI, SPXIII and SPXIV are questionable, further investigations will be done using the presented method.

The intervals of $v_{s, 30}$ can be found in Table 10, and the delineation of the zones is presented in Fig. 18. There are some spots in the map where the zone is not specified due to the lack of boring data. Soil categories according to EC8 are indicated in the Table 10. 


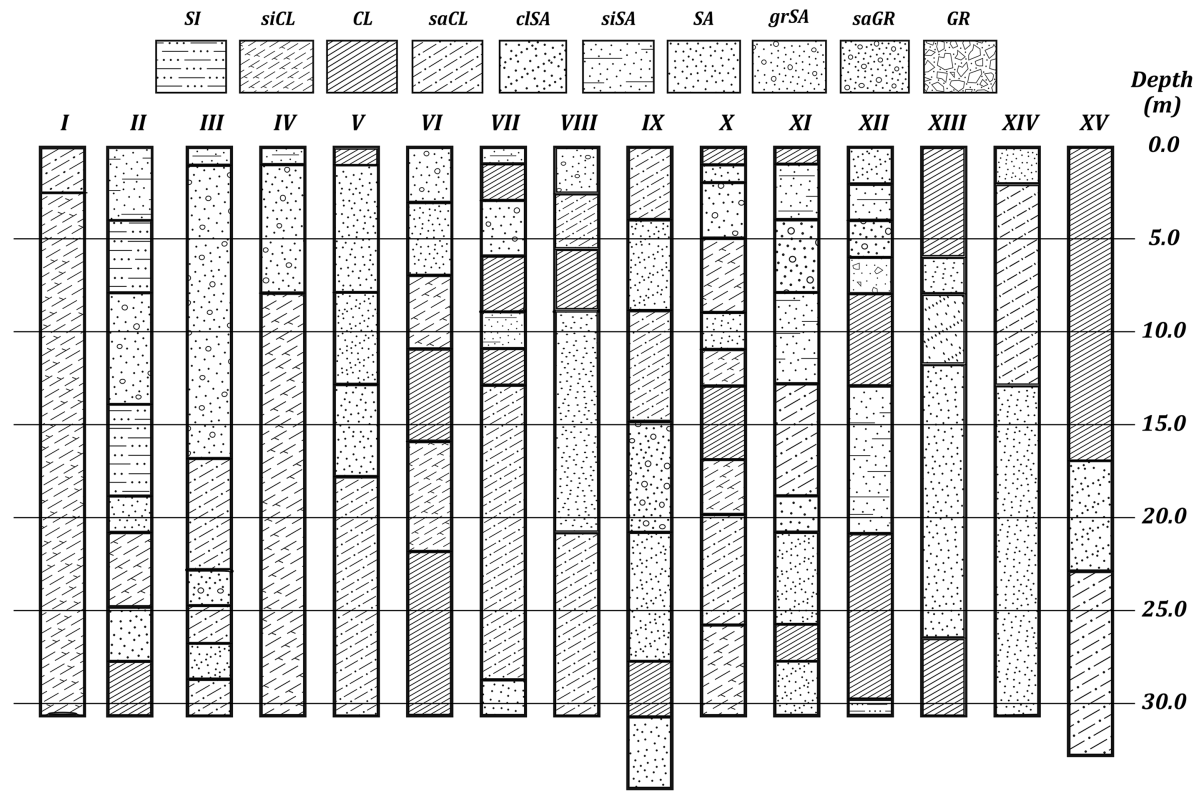

Fig. 17 Soil profiles of Győr numbered from $I$ to $X V$

Table 10 Intervals of $v_{s, 30}$ and soil categories according to EC8 in Györ

\begin{tabular}{lll}
\hline Soil profiles & Intervals of $v_{s, 30}(\mathrm{~m} / \mathrm{s})$ & $\begin{array}{l}\text { Soil category } \\
\text { according to EC8 }\end{array}$ \\
\hline I & $\sim 300$ & $\mathrm{C}$ \\
II & $275-285$ & $\mathrm{C}$ \\
III & $295-300$ & $\mathrm{C}$ \\
IV & $285-295$ & $\mathrm{C}$ \\
V & $320-325$ & $\mathrm{C}$ \\
VI & $300-310$ & $\mathrm{C}$ \\
VII & $305-315$ & $\mathrm{C}$ \\
VIII & $\sim 330$ & $\mathrm{C}$ \\
IX & $290-300$ & $\mathrm{C}$ \\
X & $295-305$ & $\mathrm{C}$ \\
XI & $295-305$ & $\mathrm{C}$ \\
XII & $290-300$ & $\mathrm{C}$ \\
XIII & $\sim 315$ & $\mathrm{C}$ \\
XIV & $\sim 415$ & B \\
XV & $445-450$ & B \\
\hline
\end{tabular}


Fig. 18 Zones with different soil profiles in Györ

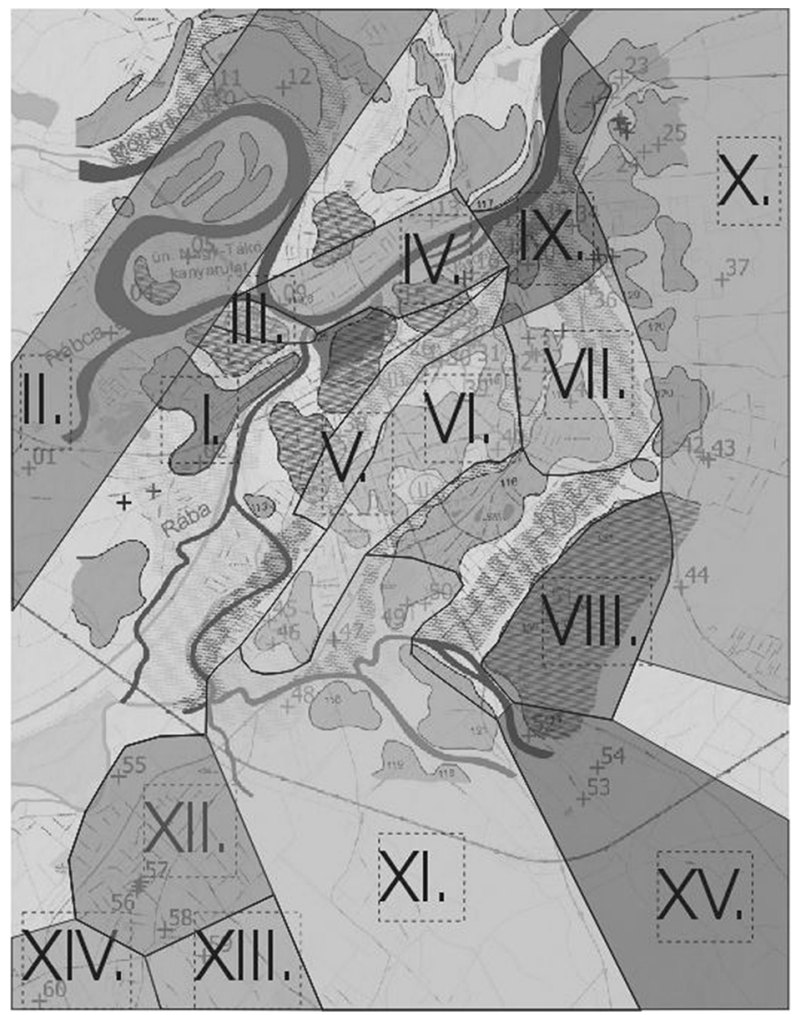

\section{Conclusions}

One alternative to determine the effects of soil layers is to use the values of $v_{s, 30}$, the equivalent $\mathrm{S}$-wave velocity that is the weighted average of $\mathrm{S}$-wave velocities in the upper $30 \mathrm{~m}$. The measured MASW data were correlated to CPT and soil boring data and developed empirical relationships between soil types, soil depth and S-wave velocity. Based on S-wave profiles 15 zones were determined in Györ. The basic intention in assessing the ground shaking intensity is to estimate the effects of local site conditions. This decision should be made on all the available results from site identifications from average of S-wave velocity to results of site response analysis. The main objective is to estimate more accurately the ground motion characteristics during possible earthquakes taking into account all the main controlling factors.

One of the main reasons to perform these correlations was to develop more accurate soil $v_{s, 30}$ profiles. While most profiles were classified as EC8 Type C, they produced very different surface responses when analyzed using 1-dimensional free-field analysis. These very different computed responses justified the efforts to generate more accurate profiles. Details of these analysis will be presented in a future paper.

Acknowledgments Data processing of the research concerning seismic risk assessment of Györ was supported by the European Union and the State of Hungary, co-financed by the European Social Fund in the framework of TÁMOP 4.2.4. A/2-11-1-2012-0001 'National Excellence Program' (2013/2014). 


\section{References}

Bard P-Y (1997) Local effects on strong ground motion: basic physical phenomena and estimation methods for microzoning studies. In: Proceedings of SERINA—seismic risk: an integrated seismological, geotechnical and structural approach, Thessaloniki, Greece

Bauer RA, Su W-J, Counts RC, Karaffa MD (2007) Shear wave velocity, geology and geotechnical data of earth materials in the central US urban hazard mapping areas. Final technical report. Illinois State Geological Survey, Champaign

Bouchon M, Barker JS (1996) Seismic response of a hill: the example of Tarzana, California. Bull Seismol Soc Am 86:66-72

Carvalho J et al (2009) Seismic velocities and geotechnical data applied to the soil microzoning of western Algarve, Portugal. J Appl Geophys 68(2):249-258

Committee on National Earthquake Resilience (2011) National earthquake resilience: research, implementation, and outreach. National Academies Press, Washington, DC

Cs. Deseő É (1989) Surface and ground waters. In: Balásházy L, Somogyi S (eds) National atlas of Hungary. MTA Földrajztudományi Kutatóintézet, Budapest, pp 62-76

European Committee for Standardization (2013) Eurocode 8: design of structures for earthquake resistance MSZ EN 1998-1:2004/A1:2013. Brussels

GeoRisk Earthquake Engineering Ltd (2006) Seismic hazard map of Hungary. http://georisk.hu/. Accessed 3 May 2014

Grünthal G (ed) (1998) European macroseismic scale 1998. European Seismological Commission, Luxembourg

Hardin BO, Black WL (1968) Vibration modulus of normally consolidated clay. J Soil Mech Found Div ASCE 95(2):353-369

Jibson RW (1987) Summary of research on the effects of topographic amplification of earthquake shaking on slope stability. USGS open-file report: 87-268. US Geological Survey

Kanli AI et al (2006) $\mathrm{V}_{\mathrm{s} 30}$ mapping and soil classification for seismic site effect evaluation in Dinar Region, SW Turkey. Geophys J Int 165:223-235

Kegyes-Brassai OK (2015) Earthquake hazard analysis and building vulnerability assessment to determine the seismic risk of existing buildings in an urban area. PhD Dissertation (defense: 2014) edition, Széchenyi István University, Györ

Luco N et al (2007) Risk-targeted versus current seismic design maps for the conterminous United States. In: SEAOC Convention, Squaw Creek, California

Martinez M (2014) CNN: six things we've learned since 1994 Northridge Earthquake. http://edition.cnn. com/2014/01/16/us/northridge-earthquake-things-learned/. Accessed 30 April 2014

Matsuoka M, Wakamatsu K, Fujimoto K, Midorikawa S (2005) Average shear-wave velocity mapping using Japan engineering geomorphologic classification map. J Struct Mech Earthq Eng 23(1):239-251

Nottis GN (2001) Multidisciplinary Center for Earthquake Engineering Research. http://mceer.buffalo.edu/ education/reu/01presentations/swvlwrhudson.htm. Accessed 12 Feb 2014

Paoletti V (2012) Remarks on factors influencing shear wave velocities and their role in evaluating susceptibilities to earthquake-triggered slope instability: case study for the Campania area. Nat Hazards Earth Syst Sci 12:2147-2158

Park CB, Miller RD, Xia J (1998) Imaging dispersion curves of surface waves on multi-channel record. In: SEG, 68th annual meeting, technical program with biographies, New Orleans, Louisiana

Park CB, Miller RD, Xia J (1999) Multichannel analysis of surface waves (MASW). Geophysics 64:800-808

Park CB, Miller RD, Xia J (2001) Offset and resolution of dispersion curve in multichannel analysis of surface waves (MASW). In: Proceedings of the SAGEEP, Denver

Park Seismic LLC (1990) Multichannel analysis of surface waves (MASW). http://www.masw.com/ DataAcquisition.html. Accessed 4 May 2014

Perrin ND, Stephenson WR, Semmens S (2010) Site class determinations (NZS 1170.5) in Wellington using borehole data and microtremor techniques. In: New Zealand Society for Earthquake Engineering conference proceedings, Wellington, New Zealand

Robertson PK, Cabal K (2012) Guide to cone penetration testing for geotechnical engineering, 5th edn. Gregg Drilling and Testing, Inc., Signal Hill

Scharek P (ed) (1990) South Györ. In: The geological map series of the Little Hungarian Plain. Magyar Állami Földtani Intézet, Budapest

Scharek P (ed) (1991) North Györ. In: The geological map series of the Little Hungarian Plain. Magyar Állami Földtani Intézet, Budapest 
Scharek P, Tóth G (1994) A természetvédelmi területek földtani és hidrogeológiai elemzése (Geological and hydrogeological analysis of the natural reservation areas). Magyar Állami Földtani Intézet, Budapest

Southern California Earthquake Center (2001) A comparison of the February 28, 2001, Nisqually, Washington, and January 17, 1994, Northridge, California Earthquakes. http://www.scec.org/news/01news/ feature010313.html. Accessed 30 April 2014

Szilvágyi Z (2012) Dinamikus talajparaméterek meghatározása (Determining the dynamic soil properties). In: Fülöp P (ed) szerk. Tavaszi Szél, Konferenciakötet (Spring Wind 2012 Conference Proceedings). Doktoranduszok Országos Szövetsége, Budapest, pp 458-465

Trifunac MD, Hudson DE (1971) Analysis of the Pacoima Dam accelerograms-San Fernando Earthquake of 1971. Bull Seismol Soc Am 61:1393-1411

Varga P (2014) Az 1763. évi komáromi földrengés (The Komárom Earthquake of 1763). Természet Világa, $145(2)$

Vidale JE, Helmberger DV (1988) Elastic finite-difference modeling of the 1971 San Fernando, California Earthquake. Bull Seismol Soc Am 78(1):122-141

Wair BR, DeJong JT, Shantz T (2012) Guidelines for estimation of shear wave velocity profiles. PEER report 2012/8. Pacific Earthquake Engineering Research Center Headquarters at the University of California, Berkeley 